\title{
Yenidoğan kemik enfeksiyonları ve kronik non-bakteriyel osteomiyelit
}

\section{Newborn bone infections and chronic non-bacterial osteomyelitis}

\author{
Deniz Gezgin Yıldırım¹, Sevcan A. Bakkaloğlu² \\ 1Diyarbakır Çocuk Hastanesi, Çocuk Romatolojisi Bölümü, Diyarbakır \\ ${ }^{2}$ Gazi Üniversitesi Tıp Fakültesi, Çocuk Sağlı̆̆ı ve Hastalıkları Anabilim Dalı, Çocuk Romatolojisi Bilim Dalı, Ankara
}

\begin{abstract}
Osteoartiküler enfeksiyonlar yenidoğanlarda daha büyük çocuklar ve adolesanlardan farklı ve daha ciddi bir seyir gösterir. Akut hematojen osteomiyelit en sık görülen formdur ve genellikle etkenler Staphylococcus aureus, gram negatif bakteriler ve grup B streptococcus'lardır. En sık görülen enfeksiyon bölgesi uzun kemiklerin metafizi olup, kolayca komşu epifiz ve ekleme yayılabilir. Yenidoğanlarda psödoparalizi dışında özgün bulgu ve semptom olmadığından tanı koymak zordur. Klinik şüphe esas olup, tanıda görüntüleme yöntemleri, laboratuvar tetkikleri ve kültür örneklerinden yararlanılır. Tedavide 3-4 hafta intravenöz, ardından oral antibiyotik uygulanır. Antibiyotik tedavisine yanıtsızlık durumunda ya da abse varlığında cerrahi müdahale yapılmalıdır. Sıklıkla uzun kemiklerin metafizlerini etkileyen ve enfeksiyöz osteomiyelitle ayırıcı tanı güçlüğüne neden olan daha nadir bir neden, kemik ve kan kültürlerinin tipik olarak negatif olduğu kronik non-bakteriyel osteomiyelittir (KNO). Kronik tekrarlayan multifokal osteomiyelit olarak da bilinir. Özellikle çocukları etkileyen, kemik ağrısı ve ateş, alevlenme ve iyileşme dönemleri ile karakterize oto-enflamatuvar bir kemik hastalığıdır. Patogenezi tam aydınlatılamamıştır. Genellikle multifokal ve simetrik tutulum beklenmekle birlikte unifokal de olabilir. Uzun kemiklerin metafizine ek olarak mandibula, klavikula, pelvis ve spinal kemikler de etkilenebilir. Bakteriyel osteomiyelit ve malignite dışlanarak tanı konulmaktadır. Asemptomatik kemik lezyonlarını saptamak için tüm vücut manyetik rezonans görüntüleme veya kemik sintigrafisi yararlıdır. Tedavide non-steroidal anti-enflamatuvar ilaçlar, kortikosteroidler, TNF- $\alpha$ inhibitörleri ve bisfosfonatlar etkilidir. Bu grup hastalık spektrumunda yer alan Majeed ve interlökin-1 reseptör antagonist eksikliği sendromları yenidoğan döneminde enfeksiyöz olmayan osteomiyelite neden olan nadir hastalıklar olup, ayırıcı tanıda akla getirilmelidir.
\end{abstract}

Anahtar sözcükler: yenidoğan; kas-iskelet sistemi; enfeksiyon; kronik non-bakteriyel osteomiyelit

\begin{abstract}
Osteoarticular infections have a distinct and a more severe disease course in neonates compared to older children and adolescents. Acute hematogenous osteomyelitis is the most common form, and the most frequently observed etiologic agents are Staphylococcus aureus, gram negative bacteria and group B streptococci. The metaphyses of long bones are the most common infection sites and infection may spread to the neighbouring epiphyses and joints. Diagnosis is difficult in neonates due to the lack of specific signs and symptoms other than pseudoparalysis. When clinically suspected, imaging methods, laboratory tests and culture samples are helpful. Antibiotic treatment should be given intravenously for 3-4 weeks, then continued orally. Surgical intervention should be performed in case of unresponsiveness to antibiotic treatment or abscess formation. Chronic non-bacterial osteomyelitis (CNO), formerly known as chronic recurrent multifocal osteomyelitis, is a rare condition commonly affecting metaphyses of long bones with negative bone and blood cultures and may cause diagnostic challenge in distinguishing from bacterial osteomyelitis. It is an auto-inflammatory bone disease that affects children in particular, characterized by periods of bone pain and fever, exacerbations and remissions. The pathogenesis is not elucidated. The disease is usually multifocal and symmetrical, but may also be unifocal. Although the metaphyseal region of long bones is the most commonly affected site, mandible, clavicle, pelvis and spinal bones may also be affected. Excluding bacterial osteomyelitis and malignancy is essential in making diagnosis. Wholebody magnetic resonance imaging and bone scintigraphy are helpful for detecting asymptomatic bone lesions. Non-steroidal anti-inflammatory drugs, corticosteroids, TNF- $\alpha$ inhibitors and bisphosphonates are effective in treatment. Majeed and interleukin-1 receptor antagonist deficiency syndromes are rare diseases that cause noninfectious osteomyelitis in neonatal period and should be kept in mind for the differential diagnosis.
\end{abstract}

Key words: newborn; musculoskeletal system; bone infection; chronic non-bacterial osteomyelitis

- İletişim adresi: İletişim adresi: Dr. Sevcan A. Bakkaloğlu. Gazi Üniversitesi Tıp Fakültesi, Çocuk Sağlığı ve Hastalıkları Anabilim Dalı, Çocuk Romatolojisi Bilim Dalı, 06560 Ankara Tel: 0312 - 2025233 e-posta: sevcan@gazi.edu.tr

- Geliș tarihi: 18 Haziran 2020 Kabul tarihi: 29 Haziran 2020 
elişmemiş ülkelerde daha sık görülen, akut hematojen, subakut fokal ve kronik olmak üzere üç alt tipi bulunan osteomiyelit, yenidoğan döneminde kemik ve eklemlerde kalıcı hasara neden olabilir. Bu nedenle erken tanı ve tedavisi büyük önem taşımaktadır. ${ }^{[1]}$ Çocuklarda yılda 1000'de 0.2-1.6 oranında izlenir ve kız çocuklarında erkeklere göre 2.5 kat daha sıktır. Osteoartiküler enfeksiyon hematojen yoldan, penetran yaradan ya da bitişik enfeksiyondan lokal olarak yayılabilir. Yenidoğanlarda daha çok akut hematojen osteomiyelit görülmektedir. ${ }^{[2]}$ Osteoartiküler enfeksiyonların belirti ve semptomlarının yenidoğan döneminde silik ve non-spesifik olması nedeniyle tanı koymak büyük çocuklara göre daha zordur. Psödoparalizi dikkat çekici bir bulgu olabilir. Prematüre doğum, perinatal asfiksi, göbek kateterizasyonu, sepsis ve idrar yolu enfeksiyonu risk faktörleridir. ${ }^{[3]}$

Kronik non-bakteriyel osteomiyelit (KNO) ilk olarak 1972'de Giedion ve ark. ${ }^{[4]}$ tarafindan tanımlanan, iyileşme ve alevlenme dönemleri ile seyreden, etyolojisi bilinmeyen, idiyopatik oto-enflamatuvar bir kemik hastalığıdır. Oto-enflamatuvar hastalıklar doğal immun sistemin aşırı aktivasyonu ile ortaya çıktığından tipik olarak otoreaktif lenfosit ya da otoantikor gelişimi yoktur. ${ }^{[5]}$ Bu gruptaki monogenik geçişli Majeed ve interlökin-1 reseptör antagonist eksikliği (DIRA) sendromları erken başlangıçıı enfeksiyöz olmayan osteomiyelite neden olmaktadır. ${ }^{[6,7]}$

$\mathrm{Bu}$ derlemede yenidoğan dönemindeki kasiskelet enfeksiyonları ile ayırıcı tanıda karşımıza çıkabilecek kronik non-bakteriyel osteomiyelitten bahsedilecektir.

\section{YENIDOĞAN ENFEKSIYONLARI}

\section{Etyoloji}

Septik artrit ve osteomiyelitin bakteriyel etyolojisi yaş gruplarına göre değişkenlik göstermektedir. Yenidoğanlarda Staphylococcus aureus, gram negatif bakteriler ve grup B streptococcus'lar en sık gözlenen patojenlerdir. Coagulase negative staphylococcus'lar yenidoğan yoğun bakım ünitelerinde intravasküler girişimler sonrası gelişen nozokomiyal enfeksiyonlarda etkendir. Aşılama ile sıklığı belirgin azalmış olan Haemophilus influenzae tip B (Hib) beş yaş altı çocuklarda \%10 oranında etken olarak izlenirken, Hib aşılama programı bulunmayan fakir ülkelerde halen önemli bir septik artrit etkenidir. Orak hücre anemili çocuklarda Salmonella osteomiyeliti görülebilir. Diğer nadir kas-iskelet sistemi enfeksiyon etkenleri Staphylococcus pyogenes, Pneumococcus, Pseudomonas aeruginosa ve Neisseria türleridir. ${ }^{[8]}$

\section{Patogenez}

Hematojen osteomiyelit genellikle alt ekstremitedeki uzun tübüler kemiklerde görülür. Bu kemiklerin sinoviyal membran kanlanması fazladır ve bakterilerin sinoviyal alana yayılmasını engelleyecek bir bazal membran da yoktur. Enfeksiyon retikülo-endotelyal hücre azlığı nedeniyle metafiziyel alanda oluşmaktadır. Metafizo-epifiziyel bileşkedeki kapiller ağ ve sinusoidal venler nedeniyle yavaşlayan kan akımı bakterilerin çoğalması için ideal bir ortam oluşturur. Septik artrit, bitişik osteomiyelit alanının yayılımından da kaynaklanabilir. ${ }^{[9]}$ iki yaşın altındaki çocuklarda epifiz, fizisi çaprazlayarak geçen metafizer damarlar ile beslenmektedir. Bu damarlar aracılı̆̆ıla metafizdeki enfeksiyon rahatlıkla epifize, hatta eklem içerisine yayılıp septik artrite neden olabilir. İki yaş üstü çocuklarda fizis bariyer görevi yaparak enfeksiyonun metafizde sınırlı kalmasını sağlasa da, yenidoğanlarda bu bariyer yoktur. Ayrıca kortikal kemikleri de ince ve gevşek olduğundan enfeksiyon kolayca subperiostal bölgeye yayılarak subperiostal abse ile sonuçlanabilir. Süpüratif enfeksiyon sonrası kemik dokuda mikronekroz ve ardından sekestrum gelişir. Fistül oluşumu yenidoğanlarda nadirdir. ${ }^{[10]}$

\section{Tanı}

Kas-iskelet sistemi enfeksiyonlarının tanısında ayrıntılı bir öykü ve fizik muayene ile laboratuvar ve radyolojik değerlendirme esastır. Erken tanı ve tedavi, kemik nekrozu ve ekstremite kısalığı gibi komplikasyonları önler. Yenidoğanlarda ateş ve sistemik bulgular büyük çocuklardan farklı olarak bulunmayabileceğinden klinikte şüphelenme önemlidir. Hareket kısıtıılığı ve psödoparalizi olabilir. Sonraki dönemde kemik enfeksiyonunun bitişik yumuşak dokulara yayılımı ile etkilenen ekstremitede lokal şişlik, Isı artışı, eritem ve hassasiyet meydana gelebilir. ${ }^{[1]}$ Yenidoğanlarda anatomik yapı ve vaskülarizasyon farklılığı nedeniyle septik artrit ve osteomiyelit genellikle birliktedir. Diğer çocukluk yaş gruplarının aksine, yenidoğan hastalarda septik artrit ve osteomiyelit birden fazla bölgede bulunabilir. En sık tibia ve femurda olmak üzere diğer uzun kemiklerde de osteomiyelit gelişebilir (tutulum sıklığı: tibia [\%50], femur [\%30], fibula [\%12], humerus [\%3], ulna [\%3] ve radius [\%2]). ${ }^{[11]}$

Laboratuvar tetkikleri kas-iskelet sistemi enfeksiyonlarının tanısında önemlidir. Akut faz belirteçleri olan C-reaktif protein (CRP), beyaz küre sayısı (WBC) ve eritrosit sedimentasyon hızı (ESR) artmıştır, ancak özgül değildir. CRP enfeksiyon başladıktan 6-10 saat sonra artıp, komplike olmayan olgularda yaklaşık bir hafta içinde normale dönerken; ESR enfeksiyon başladıktan 2-3 gün sonra artıp ve yaklaşık dört hafta içinde 
normale döner. Bu nedenle tedavi etkinlik takibinde CRP daha hassastır. Hastaların \%50'sinde kan kültüründe üreme olmaktadır. ${ }^{[10]}$

Eklem boşluğundan ve etkilenen kemik dokusundan gram boyama ve kültür için steril örnek gönderilmelidir. Septik artritte sinoviyal sıvı bulanık ve pürülandır. Sinoviyal incelemede polimorf nüveli lökositten baskın WBC düzeyinin $50.000 / \mathrm{mm}^{3}$ 'ten daha yüksek oluşu, glukoz düzeyinin düşüklügüu, protein ve laktik dehidrogenaz (LDH) düzeyinin yüksekliği septik artrit açısından anlamlıdır. Kültürlerde $\% 50-70$ oranında üreme olduğundan her zaman mikroorganizma üretilemeyeceği unutulmamalıdır. ${ }^{[12]}$

Radyolojik değerlendirme kas-iskelet sistemi enfeksiyonlarının tanısında kıymetlidir ve ilk olarak etkilenen bölgenin direkt radyografisi çekilmelidir. Enfeksiyona ikincil kemik değişiklikleri 7-10 gün sonra meydana gelmektedir. Ancak hastalığın ilk 48 saatinde de radyolusen kas planlarında bozulma ve subkutan ödem bulguları izlenebilir. Özellikle yenidoğanlarda femur başı dislokasyonu direkt grafide kolaylıkla saptanır. Yenidoğanda düz grafiler ile osteomiyelit ve ilişkili effüzyonun saptanması daha büyük çocuklara nazaran daha erken olur. Büyük çocukta eklem effüzyonunun tespiti için direkt grafinin duyarlılığı daha düşüktür. Subkondral erozyon ve aseptik nekroz göstergesi olan proksimal femur epifiz volümü azalması geç bulgulardır. ${ }^{[3]}$ Ultrasonografi (US) subkutan ödem, uzun kemiklerde subperiosteal koleksiyon ve eklem içi sıvı artışı tespitinde başarılıdır. US eşliğinde aspirasyon minimal invaziv, radyasyonsuz, ucuz ve güvenli bir tetkik ve tedavi metodudur. Kalça septik artritinin erken döneminde sıvı miktarı azken US ile tanı ve artrosentez mümkündür. Sintigrafi ile osteomiyelitin ilk 24-48 saatinde tanı konabilir. Üç fazlı teknesyum-99m ile taramanın duyarlılığı yüksektir, ancak kemik anomalilerinin varlığında özgüllüğü düşük olabilir. Abse veya iskemi varlığında kemik radyonüklid tutulumu düşer ve yanlış negatiflik gelişebilir. Septik artritte periartiküler tutulum tüm fazlarda görülür ve eklemin her iki tarafında simetriktir. Manyetik rezonans (MR) görüntüleme osteomiyelit tanısında yüksek duyarlılık ve özgüllük gösterir. Hastalığın yerleşimi ve yayılımı hakkında ayrıntılı bilgi verir. Ayrıca eklem sıvısının değerlendirmesinde ve yumuşak doku bulguları açısından bilgisayarlı tomografiden (BT) daha güvenilirdir. Ancak BT kortikal hasar, sekestrasyon ve kemik içi gaz bulgularını daha iyi gösterir. ${ }^{[13]}$

\section{Tedavi}

Kas-iskelet sistemi enfeksiyonlarının tedavi başarısı, erken tanı ve acil tedaviye bağlıdır. ${ }^{[1]}$ Uygun antibiyotik, uygun dozda kullanılmalıdır. Staphylococcus aureus, grup B streptococcus ve gram negatif bakterileri kapsayacak şekilde ampirik antibiyotik tedavisi başlanmalıdır. Eklemden alınan materyalin gram boyama, kültür ve antibiyogram testlerinin sonucuna göre düzenlenen antibiyoterapiye 4-6 hafta devam edilmelidir. ${ }^{[2]}$ Tablo 1'de uygun antibiyotik rejimleri özetlenmiştir. Kırk sekiz saat antibiyotik tedavisine rağmen yeterli yanıt alınamayan kemik içi ve yumuşak doku abseleri boşaltılmalıdır. Subperiosteal abselere uygulanan cerrahi drenaj sonrası büyüme plağı zarar görebilir. Bu nedenle yenidoğan döneminde mümkün olduğunca cerrahi müdahalelerden uzak durulmalıdır. Ancak eklem enfeksiyonlarında cerrahi drenaj yapılmalıdır. ${ }^{[1]}$

\section{KRONIK NON-BAKTERIYEL OSTEOMIYELIT}

Kronik non-bakteriyel osteomiyelit (KNO) kemik ağrısının olduğu, iyileşme ve alevlenme dönemleri ile seyreden, etyolojisi bilinmeyen, multifokal idiyopatik oto-enflamatuvar bir kemik hastalığıdır. ilk olarak 1972'de Giedion ve ark. ${ }^{[4]}$ tarafindan 'subakut ve kronik simetrik osteomiyelit' olarak tanımlanmıştır. 1978'de Probst ve ark. ${ }^{[4]}$, multifokal ve tekrarlayan kemik lezyonları nedeniyle hastalığa 'kronik tekrarlayan multifokal osteomiyelit' adını vermişlerdir. Ancak multifokal olmayan ve tekrarlama göstermeyen hastalar da tanımlanmıştır. Bu nedenle "KNO", tüm bu

Tablo 1. Etyolojiye göre yenidoğan döneminde kas-iskelet sistemi enfeksiyonlarının tedavisi ${ }^{[2]}$

\begin{tabular}{ll}
\hline Mikroorganizma & Yenidoğan hastalar için uygun antibiyotik tedavisi \\
\hline S.aureus & Nafsilin veya Kloksasilin + Gentamisin veya Sefotaksim, Seftriakson, Seftazidim \\
MRSA & Vankomisin veya Teikoplanin + Gentamisin \\
Grup A ya da B streptokok & Gentamisin veya Sefotaksim, Seftriakson, Seftazidim + Nafsilin veya Kloksasisilin \\
Gram negatif bakteri & Nafsilin veya Kloksasilin + Gentamisin veya Sefotaksim, Seftriakson, Seftazidim \\
\hline
\end{tabular}

S.aureus; Staphylococcus aureus, MRSA; metisilin rezistan Staphylococcus aureus. 
hastaları içeren "şemsiye terim" olarak kullanılmaktadır. Hastalık, ilk altı ayda düzelen, persistan seyreden ve tekrarlayıcı multifokal kemik lezyonları ile giden üç farklı seyir gösterebilmektedir. ${ }^{[15]}$ Hastalık fokal, asemptomatik ve hafif bir formda olabileceği gibi ağrılı, şiddetli, multifokal de seyredebilir. En sık uzun kemiklerin metafizoepifizer bölgesinde olmak üzere pelvis, klavikula, spinal kemiklerde izlenir. Tedavi edilmemiş olgularda, uzun süreli skleroz nedeniyle kemiklerde büyüme geriliği, spinal fraktür, ağrı ve nörolojik problemler meydana gelebilir. ${ }^{[16]}$

\section{Epidemiyoloji}

KNO prevalansı $1-2 / 1.000 .000$ ve yıllık insidansı $1 / 1.000 .000$ 'dur. Tüm osteomiyelit olgularının \%25'ini oluşturmaktadır. Etnik yapıya göre hastalık sıklığı arasında fark yoktur. Hastalık farkındalığının yüksek olmasına bağlı Asya ve Avrupa'dan daha çok olgu bildirilmiştir. Ortalama hastalık başlangıç yaşı 9-10'dur, ancak erişkin çağda da gelişebilir. Kızlarda erkeklere göre iki kat daha sık görülür. ${ }^{[16]}$ Akne ve püstülozis gibi cilt bulguları adolesan ve erişkin dönemde daha sık izlenir ve hastalık SAPHO (sinovit, akne, püstülozis, hiperostozis, osteit) adını alır. ${ }^{[17]}$

\section{Etyoloji ve Patogenez}

Patogenezi tam aydınlatılamamıştır. Tipik olarak kemik lezyonlarının kültürlerinde üreme olmaz ve histopatolojik değerlendirmede mikroorganizma görülmez. Lezyonlar antibiyotik tedavisinden yarar görmez, ancak azitromisin tedavisinin yararlı olabileceğini belirten yayınlar vardır. Bu durum azitromisinin antibiyotik etkisinden çok anti-enflamatuvar etkisine bağlanmaktadır. Propionibacterium acnes, Staphylococcus aureus, Mycoplasma hominis ve Chlamidia gibi bakterilerin KNO ile ilişkili olabileceği bildirilmiş olup, antibiyotik tedavisine yanıt alınamadığından kontaminasyon olduğu düşünülmüş̧ür. ${ }^{[5]}$

Diğer oto-enflamatuvar hastalıklarda olduğu gibi KNO'da da doğal immun sistemin aşırı aktivasyonu ile pro-enflamatuvar ve anti-enflamatuvar sitokinler arasında dengesizlik oluşmakta, bunun sonucunda osteoklast aktivasyonunda artış ve kemik dokuda remodeling ile kayıp oluşmaktadır. KNO'lu hastaların serumunda pro-enflamatuvar IL-6 ve TNF- $\alpha$ düzeylerinin arttı̆̆ı, lipopolisakkarid (LPS) ile uyarılan periferik monositlerde serum IL-1 $\beta$ üretiminde belirgin artış olduğu, öte yandan anti-enflamatuvar IL-10 düzeyinde azalma olduğu gösterilmiştir. ${ }^{[18,19]} \mathrm{KNO}$ ve IL-10 promotor polimorfizmleri arasında ilişki de bildirilmiştir. Azalmış mitogen-activated protein kinase (MAPK) sinyali, IL-10 promotorunda H3S10 fosforilasyonunda azalma, monositlerde IL-10 gen ekspresyonunu artıran transkripsiyon faktörü olan $\mathrm{Sp}-1$ seviyesinde azalma ve bunlara paralel olarak serum IL-10 salgılanmasında azalmanın patogenezde etkili bir yolak olduğu öne sürülmektedir. ${ }^{[20,21]}$

KNO'nun genetik kalıtımı ile ilgili deneysel çalışmalar yapılmıştır. KNO kliniği olan farelerde PSTPIP2 mutasyonu[ ${ }^{22]}$ ve buna ek olarak kemik remodeling'i için gerekli hücre iskeletini kodlayan gen olan FBLIM1'de mutasyon saptanmıştır. ${ }^{[23]}$ Majeed sendromu ve DIRA hastalığı monogenik kalıtımlı oto-enflamatuvar kemik lezyonları içeren hastalıklar olup, Majeed sendromu LPIN2 mutasyonuna[6], DIRA hastalığı IL1RN mutasyonuna ikincil meydana gelmektedir. ${ }^{[7]}$

\section{Klinik Bulgular}

KNO tekrarlayan kemik enflamasyonuna ikincil ağrılı, hassas lokal kemik şişliği ile karakterize bir hastalıktır. Enflamasyon iskelet sisteminin her kesiminde izlenebilir, genellikle kranium kemikleri etkilenmemektedir. Semptomlar yavaş gelişmekte ve ateş her zaman eşlik etmemektedir. Kemik ağrısı gün içinde her saat olabileceği gibi genellikle geceleri izlenmektedir. Hastalık şiddeti değişkendir, spontan remisyon olabilmektedir. Ateş, halsizlik, kilo kaybı sıktır. Artrite bağlı hareket kısıtlılığı olabilir. Hastaların yaklaşık üçte birinde Crohn, ülseratif kolit, psöriyazis gibi ek bir enflamatuvar hastalık vardır. ${ }^{[18]}$ Oto-enflamatuvar bir hastalık olan ailevi Akdeniz ateşi (AAA) ve KNO birlikteliği olan olgular da bildirilmiştir. ${ }^{[24]}$

KNO'nun en sık izlendiği kemikler; femur, tibia, pelvis, kalkaneus, omurga ve klavikuladır. Multifokal ve simetrik olabilir; \%10-20 hastada unifokaldir. Tüm yaş gruplarında klavikulanın medial üçte bir kısmını en sık etkileyen hastalık KNO'dur. En sık torakal vertebralar olmak üzere spinal kemikler olguların üçte birinde etkilenir. Kifoza neden olabilir. ${ }^{[25]}$ Çene tutulumu nadir olup erişkin hastalarda daha sıktır. Genellikle tek tarafIıdır. Kendini çenede ağrılı şişlik ile belli etmektedir. ${ }^{[26]}$

\section{Tanı}

KNO tanısı bakteriyel osteomiyelit, malignite gibi diğer hastalıklar dışlandıktan sonra konmaktadır. Klinik bulguların yanında radyolojik, histolojik, mikrobiyolojik ve laboratuvar değerlendirmeler tanı için önemlidir. Tablo 2'de Jansson ve ark.'nın KNO için önerdiği tanı kriterleri özetlenmiştir. ${ }^{[15]}$

Görüntülemede direkt grafi normaldir ya da KNO'ya özgü olmayan litik, sklerotik lezyonlar ve kemikte ekspansiyon izlenebilir. BT yüksek doz radyasyon içeren bir tetkik olduğundan önerilmemektedir. Tüm vücut MR tetkiki ile radyasyona maruz kalınmadan tüm vücut kemik ve yumuşak dokuları değerlendirilebilir ve 
Tablo 2. Kronik non-bakteriyel osteomiyelit tanı kriterleri ${ }^{[15]}$

\begin{tabular}{ll}
\hline Majör tanı kriterleri & Minör tanı kriterleri \\
\hline Radyolojik osteolitik/sklerotik kemik lezyonu & Genel durum iyiliği ve normal tam kan sayımı \\
Multifokal kemik lezyonları & CRP ve ESR düzeyinde hafif-orta düzeyde artış \\
Palmoplantar püstülozis ya da psöriyazis & Altı aydan uzun süren semptom varlığı \\
Enflamatuvar bulgular içeren, steril kemik biyopsisi & Hiperostozis \\
& Palmoplantar püstülozis, psöriyazis dışında ek bir otoimmun hastalık varlığı \\
& 1. ya da 2. derece akrabalarda KTMO, otoimmun hastalık ya da oto-enflamatuvar \\
hastalık öyküsü
\end{tabular}

CRP, C-reaktif protein; ESR, eritrosit sedimentasyon hızı; KTMO, kronik tekrarlayan multifokal osteomiyelit.

Tanı 2 majör kriter ya da 1 majör ve 3 minör kriter varlığında konmaktadır.
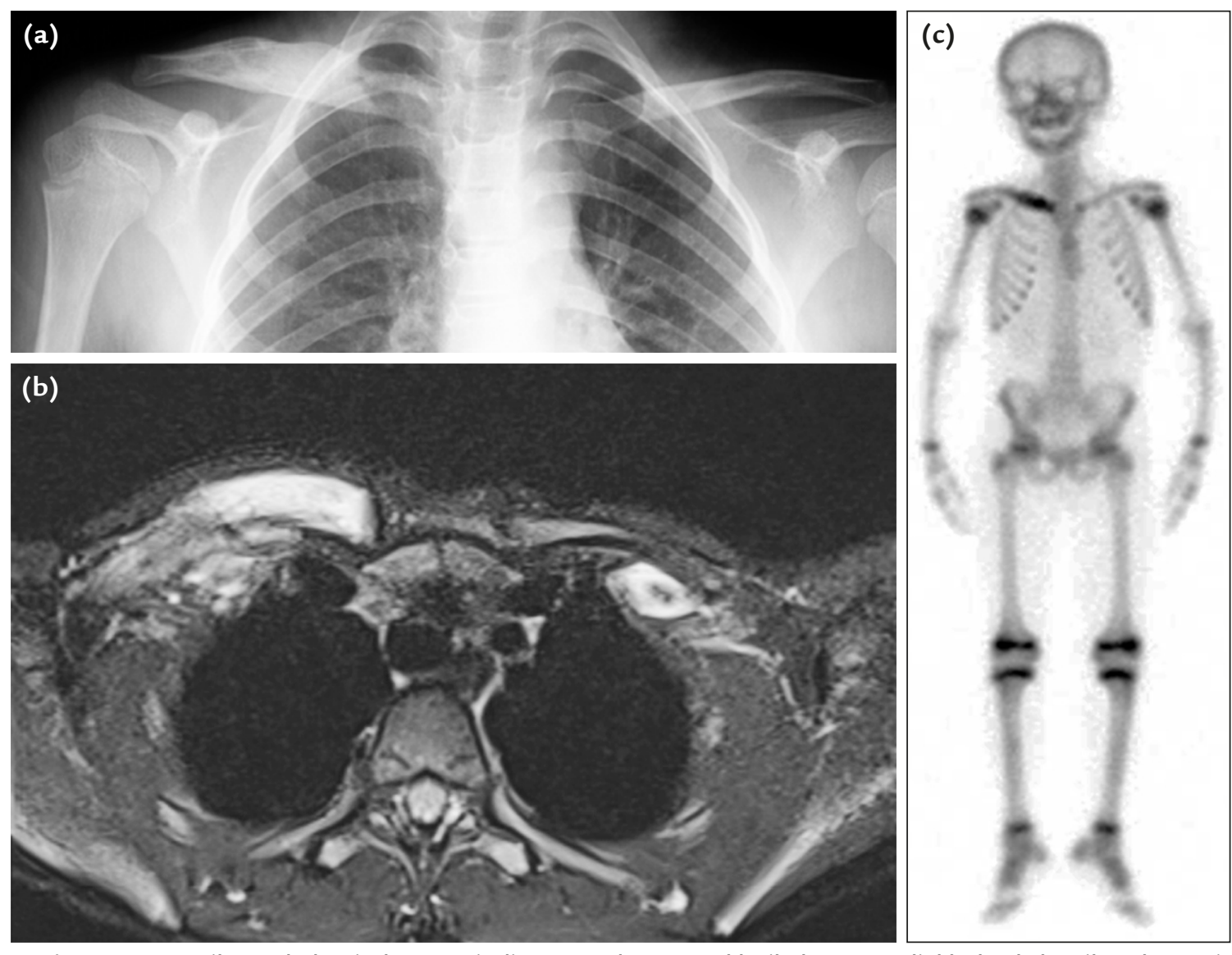

Şekil 1. a-c. Kronik non-bakteriyel osteomiyelit görüntüleme. Sağ klavikula 1/3 medial bölgede kemikte ekspansiyon (a). MRG-STIR sekansta sağ klavikula 1/3 medial alanda osteomiyelite ikincil ekspansiyon ve sklerozis (b). Tüm vücut sintigrafi Tc-99 m görüntülemede sağ klavikula 1/3 medial alanda tutulum (c).

tarama yapılarak asemptomatik lezyonlar saptanabilir. Subklinik lezyonlar en iyi STIR sekanslarda gözlenir. Ayrıca tedavi yanıtı takibinde de yararlıdır. Kemik sintigrafisi lezyon tespitinde yararlı iken lezyonların karakterizasyonu ile ilgili bilgi verememekte, ayrıca düşük doz radyasyon içermektedir. Fluorodeoxyglucose-positron emission tomography (FDG-PET) tetkikinin KNO tanısında yeri yoktur. MR'de erken dönem bulgusu olarak kemik iliği ödemi izlenirken geç dönemde litik, sklerotik kemik alanları izlenir. Daha geç dönemde hiperostozis, periosteal ödem ve yumuşak doku ödemi saptanır (Şekil 1). Bakteriyel osteomiyelit ve malignensiden ayrım zor olabilir ve biyopsi gerekebilir. KNO'da kemik biyopsileri sterildir ve özgül olmayan subakut-kronik enflamasyon bulguları izlenir. Akut evrede polimorf nüveli lökosit ve osteoklastik kemik yıkımı hâkimdir. Hastalık ilerledikçe 
lenfositler, plazma hücreleri, nadir granülomlar ile birlikte histiyositler ve artmış osteoblastik aktivite görülür. Laboratuvar tetkiklerinde ESR, CRP ve WBC gibi akut faz belirteçleri bakteriyel osteomiyelitin aksine normal ya da hafif yüksektir. ${ }^{[25]}$ Hofmann ve ark., KNO hastaları, sağlıklı popülasyon ve lösemi, lenfoma, kas-iskelet sistemi enfeksiyonları ve juvenil idiyopatik artrit hastalarında beş serum biyobelirtecini (IL-6, chemokine ligand 11 (CCL11)/eotaxin, CCL5/RANTES, collagen I $\alpha$, sIL-2R) değerlendirmişlerdir. KNO hastalarında IL-6 düzeylerinde diğer tüm gruplara göre belirgin artış saptanırken, KNO ve diğer kronik hastalığa sahip olan hastalarda sağlıklı kontrollere göre belirgin düşük serum CCL11/ eotaxin düzeyleri saptanmıştır. ${ }^{[27]}$

\section{Tedavi}

Non-steroidal anti-enflamatuvar (NSAi) ilaçlar birinci basamak olarak tercih edilecek ilaç grubudur. Çocukluk çağı KNO tedavisinde erişkinlere göre daha etkin olup, ağıı kontrolünü \%40-80 oranında sağlar. ${ }^{[28]}$ Yaşam kalitesini etkileyen ağıı varlığında NSAi tedavisine ek olarak opioidler de uygulanabilir. Oral kortikosteroid tedavisinin birçok şiddetli olguda yararlı olduğu bildirilmiştir. Olası yan etkiler nedeniyle uzun süreli kortikosteroid tedavisinden kaçınılmalıdır. ${ }^{[18]}$

Bisfosfonatların oral veya intravenöz formları uzun yıllardır KNO tedavisinde NSAi tedavisine ek olarak kullanılmaktadır. Günümüzde en sık tercih edilen bisfosfonat zoledronik asittir. Ağrı kontrolü ve yaşam kalitesi üzerine etkilidir. Semptomlarda düzelme genellikle ilk infüzyondan sonra izlenir. Tedavi süresi net değildir, ortalama olarak zoledronik asit bir yıl, pamidronat iki yıl kullanılmaktadır. Omurgalar, uzun kemikler ve çene lezyonlarında diğer tedavilere göre daha yararlıdır. Intravenöz formları oral formlardan daha etkindir. ${ }^{[28]}$

KNO patogenezinde, osteoklast aktivasyonunda TNF- $\alpha$ rol oynamaktadır ve hastaların serumlarında TNF- $\alpha$ düzeyi artmıştır. NSAi, kortikosteroid ve bisfosfonat tedavilerine yeterli yanıt alınamayan hastalarda anti-TNF- $\alpha$ tedavisi ile klinik ve radyolojik iyileşme olmaktadır. ${ }^{[18]}$ TNF- $\alpha$ inhibitörleri ve bisfosfonat tedavilerinin etkinliğini karşılaştıran randomize kontrollü çalışma henüz yoktur. Metotreksat, sulfasalazin, kolşisin, interferon- $\alpha$, interferon- $\beta$ ve azitromisin tedavilerinin yararlı olduğu olgular bildirilmiştir. ${ }^{[28]}$ Şekil 2'de KNO tedavi algoritması özetlenmiştir.

\section{MAJEED SENDROMU}

Majeed sendromu ilk olarak 1989'da Majeed tarafindan tanımlanmış, otozomal resesif geçişli LPIN2 mutasyonu ile meydana gelen oto-enflamatuvar bir hastalıktır. Klinik olarak multifokal osteomiyelit,

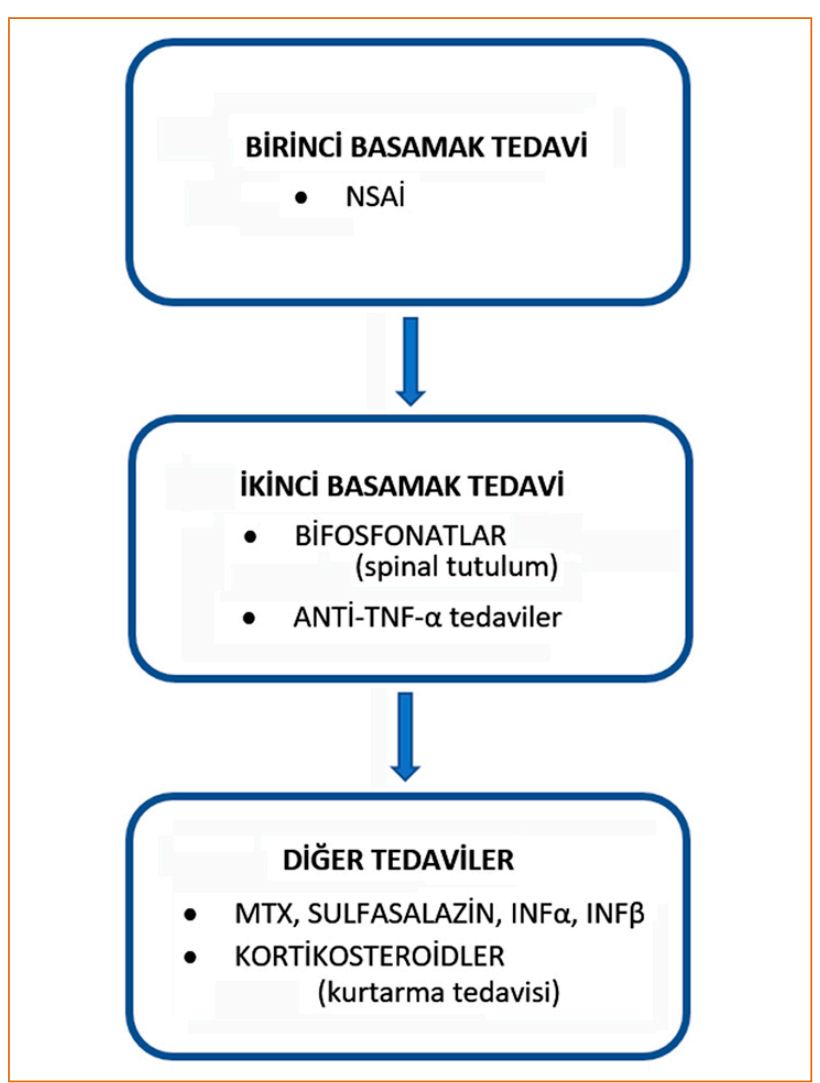

Şekil 2. Kronik non-bakteriyel osteomiyelit tedavi algoritması (NSAi, non-steroidal anti-enflamatuvar; Anti-TNF- $\alpha$, anti-tümör nekroz faktör- $\alpha$; MTX, metotreksat; INF $\alpha$, interferon $\alpha$ ).

konjenital diseritropoetik anemi ve nötrofilik dermatoz triadından oluşmaktadır. Hastalık yenidoğan döneminde ortaya çıkar. Yüksek ateş, şiddetli ağrı, kronik anemi ve artrit atakları olmaktadır. KNO gibi uzun kemiklerin metafizer bölgesi etkilenmektedir. Hastalarda büyüme geriliği, hepatomegali, eklem kontraktürleri ve kas atrofileri olmaktadır. NSAi, kortikosteroid ve antiIL-1 tedaviler yararlıdır. ${ }^{[6,29]}$

\section{INTERLÖKIN-1 RESEPTÖR ANTAGONIST EKSIKLIĞi SENDROMU (DIRA)}

DIRA sendromu IL1RN mutasyonu sonucu meydana gelen, yenidoğan döneminde ortaya çıkan yaygın püstülozis, osteit, periostit ve sistemik enflamasyon ile karakterize monogenik oto-enflamatuvar bir hastalıktır. Ateş genellikle yoktur ve serum akut faz belirteçleri belirgin yüksektir. DIRA'da izlenen osteit ve periostit geniş kemik alanlarını etkiler, şiddetlidir ve multifokaldir. Genellikle uzun kemiklerden proksimal femur bölgesinde ve vertebralarda tutulum olmaktadır. Kemik biyopsilerinde tipik olarak skleroz ve fibrozisin eşlik ettiği pürülan osteomiyelit izlenir, ancak kültürlerde üreme olmaz. Radyolojik olarak anterior kot uçlarında 
genişleme, multifokal osteolitik lezyonlar ve uzun kemik periostlarında elevasyon sık iken; proksimal femurda ossifikasyon, klavikulada genişleme, metafizer alanda ve kafa kemiğinde osteoliz daha az izlenir. Osteolitik lezyonlara ikincil vertebralarda çökme ve servikal vertebralarda füzyon gelişebilir. Anti-IL-1 tedavi yararlıdır. ${ }^{[7,30]}$

\section{KAYNAKLAR}

1. McPherson DM. Osteomyelitis in the neonate. Neonatal Netw 2002;21(1):9-22. Crossref

2. Gutierrez KM. Infectious and inflammatory arthritis. In: Long SR, Pickering LK, Prober CG, editors. Principles and Practice of Pediatric Infectious Diseases, 2nd ed. New York: Churchill Livingstone; 2003. p.475-81.

3. Offiah AC. Acute osteomyelitis, septic arthritis and discitis: Differences between neonates and older children. EurJ Radiol 2006;60(2):221-32. Crossref

4. Giedion A, Holthusen W, Masel LF, Vischer D. Subacute and chronic "symmetrical" osteomyelitis. Ann Radiol (Paris) 1972;15(3):329-42. https://pubmed.ncbi.nlm.nih. gov/4403064/

5. Jurik AG. Chronic recurrent multifocal osteomyelitis. Semin Musculoskelet Radiol 2004;8(3):243-53. Crossref

6. Ferguson PJ, Chen S, Tayeh MK, Ochoa L, Leal SM, Pelet A, Munnich A, Lyonnet S, Majeed HA, El-Shanti H. Homozygous mutations in LPIN2 are responsible for the syndrome of chronic recurrent multifocal osteomyelitis and congenital dyserythropoietic anaemia (Majeed syndrome). J Med Genet 2005;42(7):551-7. Crossref

7. Aksentijevich I, Masters SL, Ferguson PJ, Dancey P, Frenkel J, van Royen-Kerkhoff A, Laxer R, Tedgård U, Cowen EW, Pham TH, Booty M, Estes JD, Sandler NG, Plass N, Stone DL, Turner ML, Hill S, Butman JA, Schneider R, Babyn P, ElShanti HI, Pope E, Barron K, Bing X, Laurence A, Lee CC, Chapelle D, Clarke GI, Ohson K, Nicholson M, Gadina M, Yang B, Korman BD, Gregersen PK, van Hagen PM, Hak AE, Huizing M, Rahman P, Douek DC, Remmers EF, Kastner DL, Goldbach-Mansky R. An autoinflammatory disease with deficiency of the interleukin-1-receptor antagonist. N Engl J Med 2009;360(23):2426-37. Crossref

8. Morrissy RT. Bone and joint sepsis. In: Morrissy RT, Weinstein $\mathrm{SL}$, editors. Lowell and Winter's Pediatric Orthopedics. Philadelphia: Lippincott Williams \& Wilkins; 2001. p.459-500.

9. Gavilan MG, Lopez JB, Artola BS. Peculiarities of osteoarticular infections in children. Baillieres Best Pract Res Clin Rheumatol 1999;13(1):77-94. Crossref

10. Dessi A, Crisafulli M, Accossu S, Setzu V, Fanos V. Osteoarticular infections in newborns: Diagnosis and treatment. J Chemother 2008;20(5):542-50. Crossref

11. Peltola $H$, Unkila-Kallio L, Kallio MJT; Finnish Study Group. The Finnish Study Group: simplified treatment of acute staphylococcal osteomyelitis of childhood. Pediatrics 1997;99(6):846-50. Crossref

12. Shmerling RH. Synovial fluid analysis: a critical reappraisal. Rheum Dis Clin North Am 1994;20(2):503-12. https:// pubmed.ncbi.nlm.nih.gov/8016423/

13. Kothari NA, Pelchovitz DJ, MeyerJS. Imaging of musculoskeletal infections. Radiol Clin North Am 2001;39(4):653-71. Crossref

14. Probst FP, Björksten B, Gustavson $\mathrm{KH}$. Radiological aspect of chronic recurrent multifocal osteomyelitis. Ann Radiol (Paris) 1978;21(2-3):115-25. https://pubmed.ncbi.nlm.nih. gov/677736/
15. Jansson A, Renner ED, Ramser J, Mayer A, Haban M, Meindl A, Grote V, Diebold J, Jansson V, Schneider K, Belohradsky BH. Classification of non-bacterial osteitis: retrospective study of clinical, immunological and genetic aspects in 89 patients. Rheumatology (Oxford) 2007;46(1):154-60. Crossref

16. Chen Z, Cheng L, Feng G. Bone inflammation and chronic recurrent multifocal osteomyelitis. Eur Rev Med Pharmacol Sci 2018;22(5):1380-6. Crossref

17. Akçaboy $M$, Bakkaloğlu-Ezgü $S A$, Büyükkaragöz B, Isıyel E, Kandur Y, Hasanoğlu E, Buyan N. Successful treatment of a childhood synovitis, acne, pustulosis, hyperostosis and osteitis (SAPHO) syndrome with subcutaneous methotrexate: A case report. Turk J Pediatr 2017;59(2):184-8. Crossref

18. Taddio A, Zennaro F, Pastore S, Cimaz R. An update on the pathogenesis and treatment of chronic recurrent multifocal osteomyelitis in children. Pediatr Drugs 2017;19(3):165-72. Crossref

19. Scianaro R, Insalaco A, Bracci Laudiero L, De Vito R, Pezzullo M, Teti A, De Benedetti F, Prencipe G. Deregulation of the IL$1 \beta$ axis in chronic recurrent multifocal osteomyelitis. Pediatr Rheumatol Online J 2014;12(1):30. Crossref

20. Hamel J, Paul D, Gahr M, Hedrich CM. Pilot study: possible association of IL10 promoter polymorphisms with CRMO. Rheumatol Int 2012;32(2):555-6. Crossref

21. Hofmann SR, Schwarz T, Möller JC, Morbach H, Schnabel A, Rösen-Wolff A, Girschick HJ, Hedrich CM. Chronic non-bacterial osteomyelitis is associated with impaired Sp1 signaling, reduced IL10 promoter phosphorylation, and reduced myeloid IL-10 expression. Clin Immunol 2011;141(3):317-27. Crossref

22. Ferguson PJ, Bing $X$, Vasef MA, Ochoa LA, Mahgoub A, Waldschmidt TJ, Tygrett LT, Schlueter AJ, El-Shanti H. A missense mutation in pstpip2 is associated with the murine autoinflammatory disorder chronic multifocal osteomyelitis. Bone 2006;38(1):41-7. Crossref

23. Cox AJ, Zhao Y, Ferguson PJ. Chronic recurrent multifocal osteomyelitis and related diseases-update on pathogenesis. Curr Rheumatol Rep 2017;19(4):18. Crossref

24. Gezgin Yıldırım D, Bedir Demirağ T, Akdulum i, Yılmaz G, Bakkaloğlu S. Chronic non-bacterial osteomyelitis coexistent with familial Mediterranean fever. Clin Exp Rheumatol 2018;36(6 Suppl 115):150. https://pubmed.ncbi.nlm.nih. gov/30582506/

25. Borzutzky A, Stern S, Reiff A, Zurakowski D, Steinberg EA, Dedeoglu F, Sundel RP. Pediatric chronic nonbacterial osteomyelitis. Pediatrics 2012;130(5):e1190-7. Crossref

26. Camison L, Mai RS, Goldstein JA, Costello BJ, Torok KS, Losee JE. Chronic recurrent multifocal osteomyelitis of the mandible: a diagnostic challenge. Plast Reconstr Surg 2018;142(1):186-92. Crossref

27. Hofmann SR, Böttger F, Range $U$, Lück $C$, Morbach $H$, Girschick HJ, Suttorp M, Hedrich CM. Serum interleukin-6 and CCL11/ Eotaxin may be suitable biomarkers for the diagnosis of chronic nonbacterial osteomyelitis. Front Pediatr 2017;5. Crossref

28. Buch K, Thuesen ACB, Brons C, Schwarz P. Chronic non-bacterial osteomyelitis: A Review. Calcif Tissue Int 2019;104(5):544-53. Crossref

29. Herlin T, Fiirgaard B, Bjerre M, Kerndrup G, Hasle H, Bing $X$, Ferguson PJ. Efficacy of anti-IL-1 treatment in Majeed syndrome. Ann Rheum Dis 2013;72(3):410-3. Crossref

30. Schnellbacher C, Ciocca G, Menendez R, Aksentijevich I, Goldbach-Mansky R, Duarte AM, Rivas-Chacon R. Deficiency of Interleukin-1 Receptor Antagonist Responsive to Anakinra. Pediatr Dermatol 2012;30(6):758-60. Crossref 